\title{
Analysis of National Land Board Authority on Land Dispute Which have not been Registered in The Land Office of Samarinda
}

\begin{abstract}
Robyatul Adawiyah ${ }^{1}$, Hadi Noor Cahyo ${ }^{2}$ and Gunarto ${ }^{3}$
Abstract. According to Article 3 letter f Presidential Regulation No. 20 of 2015 stipulates that the National Land Agency performs functions include formulation and implementation of policies in the field of control and the handling of disputes and case land. Most of land that has not been registered in BPN Samarinda because of several problems, one status each land dispute. The purpose of this study was to analyze the authority BPN Samarinda on disputed land which has not been registered and analyzing obstacles and solutions. Metode approach used in this study is a sociological juridical approach. Mechanical collection of legal materials in this study is by interview and literature study techniques, data analysis techniquesdescriptive analytic method is used.

The results showed that the Authority granted to BPN in resolving land disputes is procedurally done by first conducting studies and approaches to the parties to the dispute, namely through consultation and the courts / litigation.

Barriers BPN authority over land disputes that have not been registered at the BPN Samarinda is the lack of public knowledge about the land, the lack of public awareness and public access to information and services is still minimal, most people live in rural surroundings with facilities and means of transport and communications are limited. BPN solutions that can be done is through deliberative approach, but if consensus is not reached, it will be taken by the courts / litigation. Also BPN proactive approach with mobile services from village to directly deal with the public in the form of activities, socialization, education, land registration, measurement and delivery of certificates.

Keywords: BPN Authority; Land Registry; Land Dispute.
\end{abstract}

\section{Introduction}

Increasing advancement of the people's economy and national economy, it also increased the purposes of legal certainty roots in the land sector. The main principle of registration of land rights is to facilitate security over land ownership and transfer of rights, for example, buyers will enjoy the ground with no interference of others. In addition, land registration is made to find whether there are the rights of third parties. The principal ideas in the registration system is to record the rights to land, and then replace the proof of ownership of land titling. The principle of land registration must reflect a rigor regarding the ownership of the land and of third parties that affect it. ${ }^{4}$ Land registration is a prerequisite in the effort to organize and regulate the establishment, control, ownership and land use to address various issues including land. The land registry is intended to grant certain rights and legal protection for rights holders on the ground with a certificate proving ground, as an instrument for

\footnotetext{
${ }^{1}$ Student of Master of Notary Law Faculty Of Law Universitas Islam Sultan Agung email ribie2104@gmail.com

2 Students of Master of Law, Faculty of Law, Universitas Islam Sultan Agung email h44dinc@gmail.com

${ }_{3}^{3}$ Lecturer in Faculty of Law UNISSULA Semarang

${ }^{4}$ Mark P. Thompson 2001 Modern Land Law First Published Oxford University Press New York p. 88
} 
structuring and ownership of land as well as an instrument for controlling the use and exploitation of land. Registration of land rights is the guarantee of the state, and an instruments are important for the protection of landowners. Land registration is rechtkadaster which includes: 1) surveying, mapping, and soil bookkeeping; 2) registration of such rights; 3 ) granting land certificates are valid as evidentiary tool. ${ }^{5}$

The rights to land have described an individual's right to property ${ }^{6}$ must be registered in the land registry. In the system of registration of land rights, recordation of the deed describes a detailed summary of the occurrence of belonging and ownership changes, or other transactions that affect a property you want to act that affects an inheritance recorded in one document. In case of land purchase part of the land owners of land for sale, carried out land registration which then issued a certificate of land, which is a proof of ownership.

If viewed from the aspect of legal acts, land rights committed in the presence of Officer land deed is an act of civil, the lawsuit against the legal action is a competence of courts of general jurisdiction and should therefore be submitted to the District Court, with judgment, if viewed from the aspect of civil law then the transaction is within the scope of civil law and therefore fall within the competence of general courts. However, if the accused is the decision of the Head of the Land Office (Administrative Officer) regarding publishing certificate, it must be submitted to the court a lawsuit TUN. So here there are two things, if the claim relates to the cancellation of the certificate, must be filed civil lawsuits are meant to be submitted to the general courts.

Land registration is series of activities undertaken by the government continuously, and regularly, includes the collection, processing, accounting, and presentation as well as the maintenance of physical data and juridical, in the form of a map and a list of field plots and units home interchanges, including the granting of a certificate as proof of its right letters for plots of existing rights and right of Ownership on Unit flats as well as certain rights which encumber. ${ }^{7}$ Thus the notion of land registration in the general provisions of Article 1 of Government Regulation No. 24 of 1997. The Land Registry organized to ensure legal certainty, the Land Registry is organized to meet the needs of the community and the government. ${ }^{8}$

It is clear that the Government Regulation No. 10 of 1961 which has been amended by Government Regulation No. 24 of 1997 has enriched the provisions of Article 19 of the BAL, namely:

- That the issuance of certificates of land rights, then the owner is given legal certainty and legal protection.

- In the information age is the Land Office as an office at the front line should be well-maintained any information required for something parcels of land either for the government itself so that it can plan the development of the country and also for the community itself that information is important to be able to decide something is needed which involved ground, the physical data juridical included for the apartment units the information is open to the public.

\footnotetext{
5 J.B. Daliyo \& kawan-kawan 2001 Hukum Agraria I Cet. 5 Prehallindo Jakarta p.80

${ }^{6}$ Margaret L. Barron 1992 Fundamentals of Business Law McGraw Hill Book Company Australia Pty Limited Australia p.39.

${ }^{7}$ Boedi Harsono 1999 Hukum Agraria Indonesia Sejarah Pembentukan Undang-Undang Pokok Agraria Isi dan Pelaksanaannya Jilid 1 Hukum Tanah Nasional Djambatan Revision Edition Jakarta p. 460

${ }^{8}$ National Land Agency 1989 the Association of Land Registry Paper March 1989 Jakarta p.44.
} 
- For that need the orderly administration of land used as a natural thing. ${ }^{9}$

National Land Agency (BPN) in Indonesia is the highest institution in the land sector, including the resolve land disputes that occurred in Indonesia. One of the missions of BPN is to realize a harmonious order of life together with resolve disputes, conflicts and cases of land throughout the country and arrangement of legal instruments and the land management system that does not give birth to disputes, conflicts and cases in the future. BPN mission of understanding and it can be concluded that the BPN as the highest Organization in Indonesia in the land sector, also in resolving land disputes and not the exception in resolving land disputes has not been registered.

Land has not been registered in reality is still prevalent in society, not only in the countryside but also commonly found in urban areas. This shows that many people who feel comfortable living or controls the land has not been registered only with proof girik, letter, Petok, rincik, or the ketitir.

On the field, in fact BPN could not give the best solution if the land is not registered it became the object of dispute, the principle of legal certainty in intimated in certifying the ground is still not meet the principle of legal justice (which is showcased in the mission of the National Land Agency) to people who have the land has not been registered and only had evidence girik, letter, Petok, rincik, or the ketitir.

Actually BPN has made efforts to attract landowners have not yet registered to register land or certifying, as Prona and Larasita. But the shuttle program as Prona or Larasita ball in practice is still not optimal.

The purpose of this study is to analyze the authority of the National Land Agency to land disputes that have not been registered in the National Land Agency Samarinda and to analyze Barriers and Solutions to the authority of the National Land Agency land dispute that has not been registered at the BPN Samarinda. Metode approach used in this study is a sociological juridical approach. Mechanical collection of legal materials in this study is by interview and literature study techniques (study document). Interviews will be conducted by employees of BPN Samarinda and Samarinda Communities will be selected randomly. Data analysis techniquedescriptive analytic method is used, so that not only do the exploration and clarification of the phenomenon or social realities but also seek causality and interactional selected from all the data collected. ${ }^{10}$

\section{Results and Discussion}

2.1 The authority of the National Land Agency to land disputes that have not been registered in the National Land Agency Samarinda

The authority is the scope of public legal action, the scope of government power, not only includes the power to decree the government (bestuur), but includes the authority for the implementation of tasks, and provide authority and distribution of major powers set out in the legislation. ${ }^{11}$

Technically BPN authority stipulated in the National Land Agency No. 3 of 2011 on the Management Assessment and Case Handling the Land, which has been replaced by the Regulation of the Minister of Agrarian and Spatial Planning / Head of National Land

\footnotetext{
${ }^{9}$ A.P.Parlindungan,1999 Pendaftaran Tanah di Indonesia,(Berdasarkan Peraturan Pemerintah No. 24 Tahun 1977) Dilengkapi dengan Peraturan Jabatan Pembuat Akta Tanah (Peraturan Pemerintah No. 37 Tahun 1988) Cet I Mandar Maju Bandung p. 2

${ }^{10}$ Sanapiah Faisal 1995 Format-Format Penelitian Sosia/ Rajawali Pers Jakarta p. 25

${ }^{11}$ Ateng Syafrudin 2000 Menuju Penyelenggaraan Pemerintahan Negara yang Bersih dan Bertanggung Jawab Jurnal Pro Justisia Edisi IV Universitas Parahyangan Bandung p. 22.
} 
Agency of the Republic of Indonesia Number 11 of 2016. With this regulation it is expected that the growing land disputes get accurate and fast way for settlement completely.

It is also contained in the Presidential Decree Number 20 Of 2015 concerning the National Land Agency, that the National Land Agency as the institution NonGovernment which is under and responsible to the President has the task of carrying out government duties in the area of land in accordance with the provisions of the legislation. The duties and authority of BPN in Article 3 are as follows: ${ }^{12}$

- Preparation and adoption of policies in the area of land;

- The formulation and implementation of policies in the field of surveying, measuring and mapping;

- Formulation and implementation of policies in the field of the determination of land rights, land registration, and community empowerment;

- The formulation and implementation of policies in the field of regulation, regulation and control of land policy;

- The formulation and implementation of policies in the field of land acquisition;

- The formulation and implementation of policies in the field of control and the handling of disputes and cases of land;

- Oversight of the implementation of tasks in the BPN;

- Coordinating the implementation of tasks, coaching, and providing administrative support to all organizational units within BPN;

- Implementation of data management information sustainable food and agricultural land in the land sector information;

- Implementation of research and development in the land sector; and

- Implementation of human resources development in the land sector.

According Soerjono Soekanto dispute is the clash between persons or groups who entered into a relationship because one of the parties affected. ${ }^{13}$

One of the activities in the strategic program of BPN is the acceleration of settlement land cases. Land disputes are land disputes between natural persons, legal entities or institutions that do not have a wide impact socio-political.

Objectively land disputes caused by the increased number of high population, the extent of land available more limited, the imbalance of interests between the various parties in the social life of the community, and the lack of public awareness in the area of land, as well as defective administration and land management so often be a trigger land dispute.

The pattern of land use in the city of Samarinda follow the existing pattern of population distribution. Accumulation of a large population as contained in locations developed by the Government such as the Trade Center, the Center for Industrial and Transmigration locations where these areas already have adequate transportation. Land Use in Samarinda most widespread is paddy land not amounting to 39338 ha, or $54.79 \%$ of the area of Samarinda, followed by home building and surrounding yard of 22896 ha, or $31.89 \%$. The number of troubled land without always raising the issue of legality. Not infrequently horizontal cross-interest led to conflict between citizens, businesses and governments. ${ }^{14}$ Thus there needs to be a target that has not been certified legalize land.

\footnotetext{
${ }^{12}$ Presidential Regulation No. 20 Of 2015

${ }^{13}$ Soerjono Soekanto 1976 Mengenal Antropologi Hukum Alumni Bandung p. 26.

$14 \mathrm{http} / / /$ dinaspertanahan.samarindakota.go.id/berita/detail/target-12000-bidang-tanahtersertifikat Accessed October 172018 at 23:27
} 
Pursuant to Article 3 point f Presidential Regulation No. 20 Of 2015, BPN Samarinda has authority in the formulation and implementation of policies in the field of control and the handling of land disputes and cases. Target BPN Samarinda 2018 is a certificate of registration as much as 7 million parcels. Currently, the BPN Samarinda already doing counseling in Sub-district related to its promotion. In addition, the BPN also been collecting data to ensure certainty and juridical status of the land. ${ }^{15}$

As for the registration of the land is still disputed, BPN samarinda menggunakain an alternative solution with 2 channels, namely through non-judicial / non-litigation (negotiations / consultation, Mediation, Arbitration) and the path of legal / litigation. If the deliberation effort did not find an agreement then the concerned / parties to the dispute may submit the case to court (District Court or the Administrative Courts). ${ }^{16}$

View of the original culture of Indonesia that promote peace, harmony, mutual cooperation, mutual help and tolerance, the basic concept in the face of disagreement or dispute, where the solution are not directly to court (litigation). But usually pursued through means of family problems out of court (non litigation).

Judicial dispute resolution (litigation) is regulated in Act No. 4 of 2004 regarding Judicial Power. Under the provisions of Article 2 of Act No. 4 of 2004, that the judicial power is held by the judicial bodies, including the General Court (according to Act No. 8 of 2004 on the General Court), to investigate, hear and decide civil problems/matters, including the settlement of any disputes regarding the land as part of civil law issues in general, then the State Administrative Court (according to Act No. 9 of 2004 on State Administrative Court) are authorized to settle disputes of State Administration.

In dealing with the settlement of land disputes, pursuant to Article 3 letter $b$ Regulation of the National Land Agency Number 4 of 2006, that the BPN Regional Office has the authority to handle the settlement of land disputes. As for the implementation is done by the Field Assessment and Handling of Conflict Land Dispute and which has the task of coordinating and implementing technical guidance for handling disputes, conflicts and land matters.

In performing these duties, the Field Assessment and Handling of Conflict Land Dispute and has a function:

- preparation of plans and programs in the field of handling disputes, conflicts and land matters;

- implementation of the handling of disputes, conflicts and land matters;

- monitoring and evaluation of the handling of disputes, conflicts and land matters;

- preparing and handling problems, disputes and conflict over land legally and nonlaw; mediation and facilitation of dispute resolution and conflict over land; handling of cases in the courts;

- preparation of proposals and recommendations on the implementation decisions of the judiciary;

- research and preparation of data and preparation of the proposed cancellation and termination recommendations legal relationship between the person and / or legal entities with the ground;

- coordination and technical guidance on the handling of disputes, conflicts and land matters.

The Field Assessment and Handling Conflict Land Dispute and consists of:

\footnotetext{
${ }^{15}$ Interview with Mr. Nur Sofwan BPN Employees Samarinda 28 September 2018

16 Sarjita 2005 Teknik dan Strategi Penyelesaian Sengketa Pertanahan Tugujogja Pustaka Yogyakarta p. 9.
} 
- Section Assessment and Management and Conflict Land Dispute

- Section Land Assessment and Case Management.

Assessment and Management Section of Dispute and Conflict Land has the task of preparing the assessment and management of disputes and conflicts, cancellation and termination, cancellation and termination proposal on the legal relationship between the person and / or legal entities with the ground; implementation of alternative dispute resolution through mediation, facilitation, coordination and technical guidance.

Section Land Assessment and Case Management has the task of preparing the assessment, and settling disputes, cancellation and termination, cancellation and termination proposal on the legal relationship between the person and / or legal entities with the land as the implementation of decisions of the judiciary as well as the coordination and technical guidance. ${ }^{17}$

In addition to the law will achieve the goal, settlement of land disputes by BPN also expected to be an alternative to people seeking justice amid the lack of public confidence in the judiciary. Thus the principle of checks that are simple, quick and low cost as stipulated in Article 4 Paragraph (2) of Act No. 4 of 2004, which had been considered not running as they should be adopted by the BPN through the dispute settlement mechanism in accordance with the Regulation of the Minister of Agrarian and Tata space / Head of National Land Agency of the Republic of Indonesia Number 11 Of 2016 About the Case Settlement Land.

2.2 Barriers and Solutions to the authority of the National Land Agency land dispute that has not been registered at the BPN Samarinda.

Samarinda Community still experiencing difficulties in regard to obtaining a land title, this is due to lack of coordination between institutions, the lack of public knowledge in the case of land, lack of public awareness and public access to information and services is still minimal, most people live in rural surroundings with facilities and means of transport and limited communication ${ }^{18}$.

Thus, there needs to be unification of perception between government agencies of the village, district, to BPN in providing an understanding of land issues. It is referred to in order to provide convenience in terms of knowledge as well as obtaining the land. BPN also through service approach with proactive system with mobile service from the village to directly deal with the public in the form of activities, socialization, education, land registration, measurement, delivery of certificates like Larasita program. BPN Samarinda been doing counseling and engage all relevant stakeholders so that the perception. ${ }^{19}$ Land title registration also uses non-bulk pattern. With this pattern there is the convenience provided the financing relief.

Regarding the handling of the settlement of land disputes implemented by empowerment existing in the institution BPN occur several obstacles, the parties to the dispute has shifted from the ways consensus to violent means careful to stick to the principle of each without budge, so the parties are not ready to play an active role in the settlement of disputes. Even one party may hinder completion method adopted by the agency of the National Land Agency of the Republic of Indonesia, so BPN in this case obstructed to exercise authority in resolving land disputes.

\footnotetext{
17 Apansah Jurnal Kewenangan Kantor Wilayah Badan Pertanahan Nasional Dalam Menyelesaikan Sengketa Pertanahan Untuk Mewujudkan Kepastian Hukum.

${ }^{18}$ Interview with Mr. Solomon Villagers Sidodadi Samarinda 28 September 2018

${ }^{19} \mathrm{http}: / /$ dinaspertanahan.samarindakota.go.id/berita/detail/target-12000-bidang-tanah tersertifikat accessed October 182018 at 06.00 pm
} 
In this case it is clear that factors readiness of the parties to deliberation and accept the resolution options offered BPN Samarinda, is a very important thing to remember without the readiness and willingness of the parties to deliberation, then the handling and settlement of land disputes based on the authority set out in the regulations law can not be implemented properly. The right solution if efforts are not achieved consensus was resolved those issues to the court (litigation) in order to obtain legal certainty.

\section{Closing}

\subsection{Conclusion}

Based on research, it is deduced as follows:

- BPN Samarinda authority on disputed land which has not been registered is per Local Regulation of the National Land Agency of the Republic of Indonesia Number 11 Of 2016 and Presidential Decree No. 20 of 2015, that the BPN Samarinda first collecting the data to ensure certainty and juridical status of the land. As for the registration of the land is still disputed, BPN Samarinda used an alternative solution with 2 channels, namely through non-judicial / non-litigation (negotiations / consultation or negotiation, / Conciliation, Mediation, Arbitration) and the path of legal / litigation. If the deliberation effort did not find an agreement then the concerned / parties to the dispute may submit the case to court (District Court or the Administrative Courts).

- The barriers experienced BPN Samarinda is a dispute between the parties has been no readiness to conduct deliberations, relevant parties are still firm in their stance, so it is very difficult to achieve consensus, then the last solution is the completion of the judicial path / litigation.

\subsection{Suggestion}

- BPN Samarinda should be using humanity approach with broad dimensions, and therefore the meeting is likely to be achieved.

- The people should be more open in terms of thinking to address various issues relating to land.

\section{Bibliography}

[1] A.P.Parlindungan,1999 Pendaftaran Tanah di Indonesia,(Berdasarkan Peraturan Pemerintah No. 24 Tahun 1977) Dilengkapi dengan Peraturan Jabatan Pembuat Akta Tanah (Peraturan Pemerintah No. 37 Tahun 1988) Cet I Mandar Maju Bandung.

[2] Apansah Jurnal Kewenangan Kantor Wilayah Badan Pertanahan Nasional Dalam Menyelesaikan Sengketa Pertanahan Untuk Mewujudkan Kepastian Hukum.

[3] Ateng Syafrudin 2000 Menuju Penyelenggaraan Pemerintahan Negara yang Bersih dan Bertanggung Jawab Jurnal Pro Justisia Edisi IV Universitas Parahyangan Bandung.

[4] Boedi Harsono 1999 Hukum Agraria Indonesia Sejarah Pembentukan UndangUndang Pokok Agraria Isi dan Pelaksanaannya Jilid 1 Hukum Tanah Nasional Djambatan Revision Edition Jakarta

[5] J.B. Daliyo \& kawan-kawan 2001 Hukum Agraria I Cet. 5 Prehallindo Jakarta. 
[6] Margaret L. Barron 1992 Fundamentals of Business Law McGraw Hill Book Company Australia Pty Limited Australia.

[7] Mark P. Thompson 2001 Modern Land Law First Published Oxford University Press New York.

[8] National Land Agency 1989 the Association of Land Registry Paper March 1989 Jakarta.

[9] Sanapiah Faisal 1995 Format-Format Penelitian Sosial Rajawali Pers Jakarta.

[10] Sarjita 2005 Teknik dan Strategi Penyelesaian Sengketa Pertanahan Tugujogja Pustaka Yogyakarta.

[11] Soerjono Soekanto 1976 Mengenal Antropologi Hukum Alumni Bandung.

[12] Interview with Mr. Nur Sofwan BPN Employees Samarinda 28 September 2018

[13] Interview with Mr. Solomon Villagers Sidodadi Samarinda 28 September 2018

[14] http://dinaspertanahan.samarindakota.go.id/berita/detail/target-12000-bidangtanah-tersertifikat Accessed October 172018 at 23:27

[15] http://dinaspertanahan.samarindakota.go.id/berita/detail/target-12000-bidangtanah tersertifikat accessed October 182018 at 06.00 pm

[16] Presidential Regulation No. 20 Of 2015 